\title{
STRATEGY TO IMPROVE THE EFFECTIVENESS OF AIR CARGO IMPORT DELAYS
}

\author{
Maria Diana Bota Mukin ${ }^{1}$, Adjie Farhan ${ }^{2}$, Sekar Widyastuti Pratiwi ${ }^{3}$ \\ 1. STMT Trisakti, 2. STMT Trisakti, 3. STMT Trisakti \\ Corresponding author: Mariadianaaa@gmail.com
}

\begin{abstract}
The process of transfering modal at the airport has an important role in receiving goods. Related to the fulfillment of the capacity of the acceptance schedule that happened in the cargo warehouse would result in the fullfillment of goods. the problems that occured in case of receiving goods are the delay of the time, the lack of the effectiveness in handling the imported cargo especially air cargo receivement, and the schedule capacity of goods receivement. By using qualitative method, this research would carried out a through the analysis of the existing problems. The problems could be overcome by using a tool called Radio Frequency Idenfication Technology or commonly abbreviated as RFID. RFID is a tool that has a wireless sensor that functioning as a documents's detection and store a lot of data. RFID also help overcoming the cargo delay process.
\end{abstract}

Keywords: Effectiveness; SOP; RFID; Procedure for delivery goods; delay time..

\section{Introduction}

In general Airport Operation is all operational activities at the Airport(Kelemahan, Resky, \& Simarmata, n.d.). In air cargo transport, the modal shift process at the airport has an important role related to the fulfillment of the capacity of the timetable and the receipt of goods. Mode of transportation used in the delivery of goods can be through ships, trucks / containers and aircraft.

The problems that often occur in terms of receipt of goods is the delay of time, the lack of effectiveness in the handling of imported cargo, especially the cargo receipts through the air as well as the capacity of the goods receipt schedule. Delays According to John M. Echols and Hasan Shadily (2013: 172), Delay is delay, delay, slow reaction. Thus, it can be concluded that delay is a delay caused by a slow reaction, may result in an activity being delayed and having a chain effect (Sari, 2015). The cargo time delay that occurs not only affects its progress on sequential operations, but also causes delay in other cargo. Several studies have investigated customs processes at 
air cargo terminals, particularly the characteristics of customs import process of cargo.

According to Abdul Majid and Eko Probo (2009: 5) cargo is all goods sent by land (truck / container), sea (ships), and air (aircraft). Meanwhile, according to Meriam Webster (2017) cargo is goods sent through ships, vehicles, and aircraft. According to IATA (2005: 50) cargo is all goods that are cultivated using airmail (SMU) on AWB (air waybill) and B / L (flight of landing) domestic flights for international flights. Based on the handling of cargo is divided into 2, namely General Cargo and Special Cargo (IATA 1998: 810) (Anex A, 20).

One of the advantages of air cargo transportation is fast delivery that can reduce inventory levels and freight costs, as well as shorten delivery times. Air cargo fearers usually ask the shipping party for high transportation costs. Therefore, air cargo in general has features of timeliness, high time value, and durability. Air cargo has a high enough time compared to other cargo.

The delay time that occurs in the cargo reception process will affect the original function of the cargo or reduce the surplus value on the cargo. The development and application of technology has emerged in various fields. Radio Frequency Identification (RFID) technology is method identification using means called RFID or transponder labels. RFID has a wireless sensor function that is used to retrieve remote data. This technology does not require a barcode scanner manually, and does not use the scanner tool at close range. RFID makes information acquisition tools faster, and provides more data storage space than traditional means. RFID can also avoid situations such as trunk destruction and validity that can reduce the efficiency of scanning. In addition, RFID can also change data and information stored in tags, accelerate product handling, and reduce workforce operations. RFID function has been applied to warehouse operations. RFID can also be used to overcome difficulties in the import process, such as complicated procedures and can improve the efficiency of cargo handling, especially air cargo import.

\section{Method}


Method used in this research is qualitative methodology. Qualitative method is a method of in-depth analysis (Ricardianto \& Syaputra, n.d.). According to Kriyantono, qualitative research is a phenomenon that is done by way of data collection. Data collection are divided into 2, primary data sources and secondary data sources. By using the Business Process Reengineering (BPR) comparison tool or commonly abbreviated with BPR that will redesign the thought and redesign the work plan on the process of receiving cargo generated from available sources.

\section{Discussion and Result}

\section{Increase the Eeffectiveness of air cargo imports}

According to Schemerhon John R. (1986: 35) Effectiveness is an achievement of targets as measured by comparing output. Meanwhile, according to Hidayat (1986) effectiveness is a measure that states how far the quantity, quality and time has been achieved. Currently to address the standard differences of each airline, ground handling companies are beginning to implement ISAGO or International Standards of Ground Operation. With the ISAGO, the ground handling company is considered to have an operating standard in accordance with the international safety system (Kania, n.d.).

In the air cargo transport effectiveness made by the import cargo warehouse is very inefficient. Some research data found that in several cargo warehouses there are often a buildup of schedules that cause the accumulation of goods. Cargo handling is also caused by lack of manpower in handling goods in imported cargo warehouse. Slow service loading and unloading in the field not only based on human resources, whether it is the operator of tools and human resources that are administrative but the factors of facilities and infrastructure are closely related. For example, the availability of loading and unloading tools such as Rubber Tire Gantry Crane (RTG), Reach Stacker, Head Truck, Chassis, System and others and the readiness of the tool is required to always be in excellent condition all times (Umagapi et al., 2016) 
Each warehouse has a reference to the working system SOP (standard operational procedure) in the form of actions that must be implemented by the warehouse operator so that all operational work can run smoothly. Facilities and infrastructure owned by warehouse and warehousing in each station must be sufficient and have Standard Operational Procedure. Rules and ordinances in receiving goods, arranging goods into pallets in the warehouse.

\section{Radio Frequency Identification or RFID}

At the current customs clearance network, the load carried by the same flight is randomly selected to perform the cleaning activity. Such dispatch rules do not take into account the cargo characteristics, and may increase the cost of processing delays and cargo supplies that have a high time value. As a result, to solve the above problem, the author modifies the current shipping rules, and compares the advantages with RFID. Radio Frequency or abbreviated with RFID (Hsu, Shih, \& Wang, 2009) is an identification method using tool called RFID or transponder labels used to retrieve remote data. RFID cards or letters are objects that can or can be installed or inserted into a product, which aims to identify data or goods. Basically the working principle of RFID are divided into 2, TAG and READER devices.

Here is an explanation of RFID TAG and RFID READER ;

\section{RFID TAG}

RFID TAG is a tool attached to objects that will be identified by RFID READER. RFID TAG. RFID TAG has 2 important parts:

A. Integrated Circuit or commonly abbreviated IC, which serves to store and process information, take DC voltage sent from RFID READER through induction.

B. ANTENNA used to receive and send RF signals.

\section{RFID READER}

RFID READER is a tool used to read signals provided by RFID TAG. The use of RFID TAG can be embedded in various objects used for identification purposes, such as identification of employee ID card as well as identification of goods. RFID is used to assist handling in overcoming data 
buildup. Using RFID on the data handling process does not require a manual way. RFID will store all cargo receipt data without having to record or store the data received.

\section{Before applying RFID}

First, the goods that arrive will be taken to the break down area. Break down area is the process of disassembling or decreasing cargo. The reduced cargo will be adjusted to the SMU / AWB / CN-38 manifets to be equal to the number of koli, weight, and type of goods.

After passing through the process of dismantling in the break down area, the goods will be separated into airwaybill and airwaybill recording process. Cargo will be stored in import warehouse/ acceptance import, after cargo is stored in the warehouse/ acceptance import, what will be done next is checking the physical condition of cargo that has been received and examining the documents. Then, the warehouse operator will send NOA (Notice of Arrival) to the consignee as a notification that the cargo has arrived and is ready to be picked up. At the time of consignee receive cargo, consignee will be charged warehouse rent. The next process is the inspection of customs and excise, cargo will pass through the red and green lines. After the cargo is checked by the customs and excise of , the cargo could be taken by the consignee. Seeing from the groove, the process of receiving goods manually will take a long time. The process of data separation and removal of goods is doing by the warehouse operator will slow the process itself.

Table 2.1 


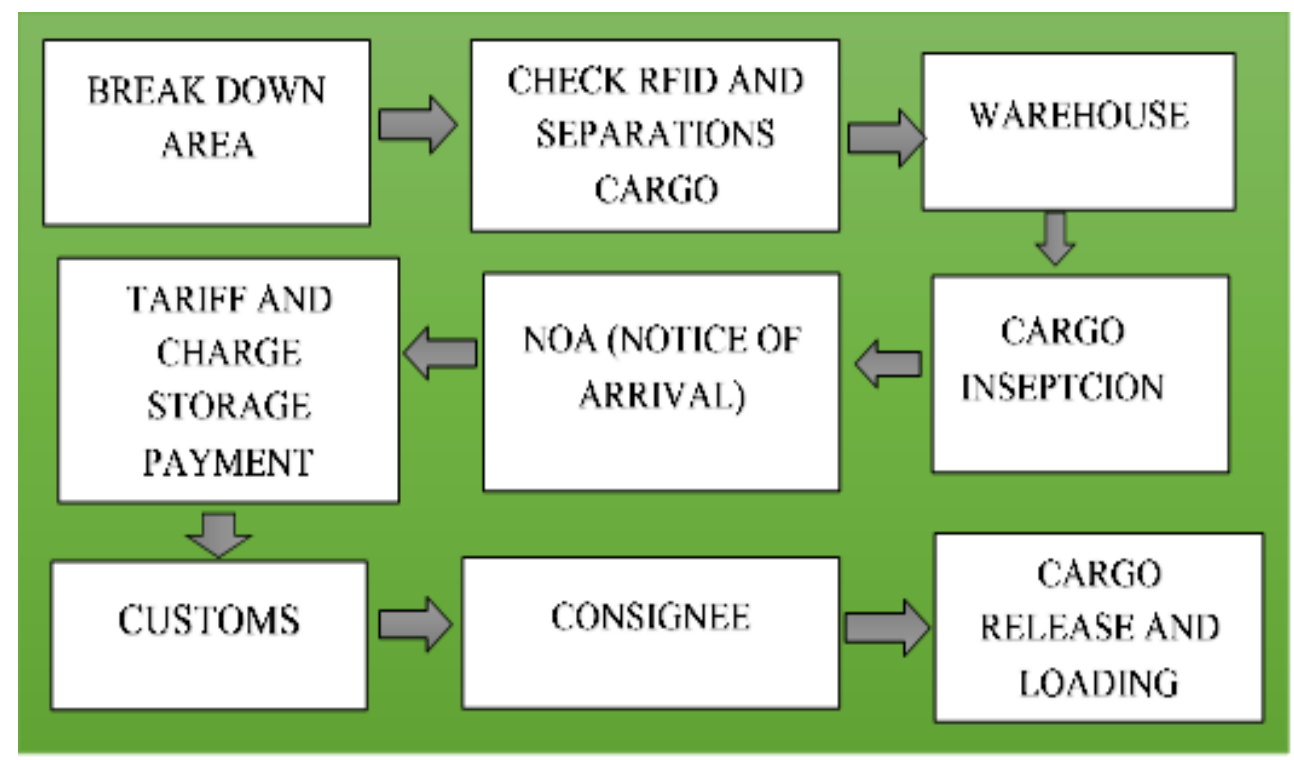

\section{After Applying RFID}

Table 2.1

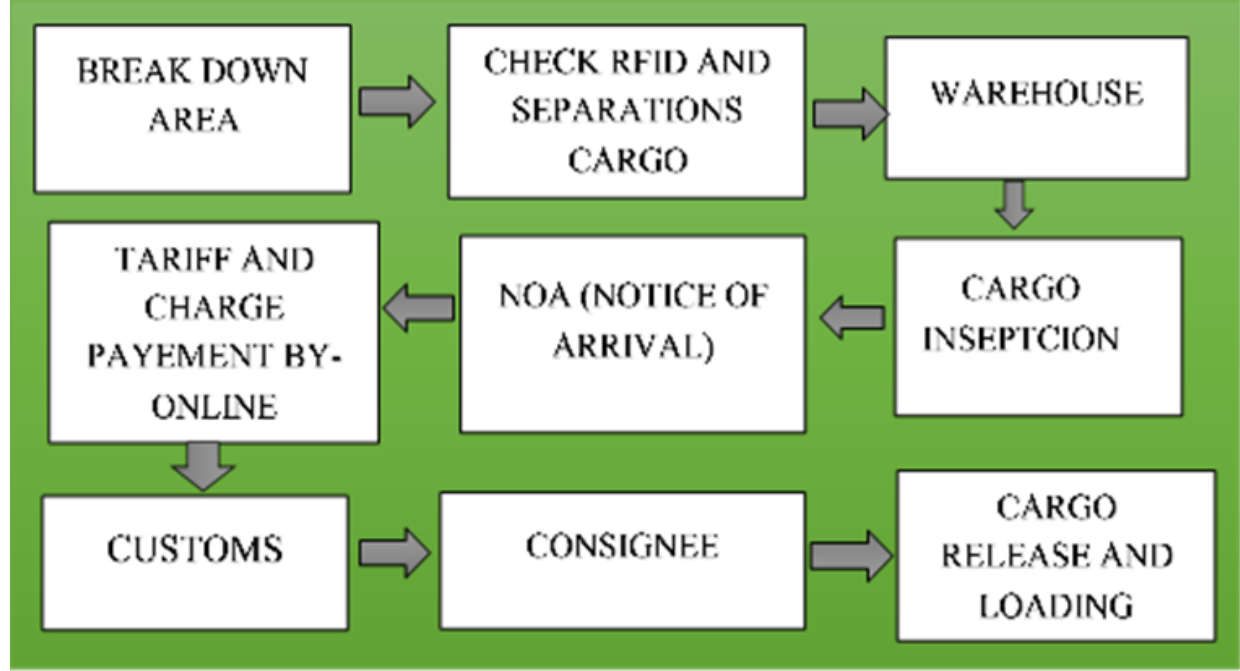

First, the goods that arrive would be taken to the break down area. The reduced cargo would be adjusted to the SMU / AWB / CN-38 manifets to be equal to the number of koli, weight, and type of goods.

After the cargo passes through the storage process in the break down area, the next process is separating the documents such as AWB and document recording. When RFID has not yet applied to the process of receiving cargo in imported cargo warehouse, the process of recording as well as data storage is done in a manual manner. It is manually done by the warehouse operator and could causing the risk of human error. After the 
goods pass the storage process in the break down area, the documents and goods are received and would be attached RFID label on the documents and goods that come. This RFID label serves to check the validity of the document and can adjust the existing items with existing documents. This RFID label will connect to the existing system in the warehouse. RFID implementation can also assist the process of delay in the existing cargo, so there is no accumulation of goods in pallets in the warehouse.

In the current cargo receipt process, the load carried by the same flight is chosen randomly to perform the cleaning activity. Such acceptance rules, do not take into account the characteristics of cargo, and may increase the cost of delays in cargo processes and inventories that have a high time value.

\section{Conclusion}

Before using RFID, the checking and receiving operators need to go to the exchange area and conduct import cargo inspection and receipt activities. With the use of RFID, this activity can be ignored because it implements RFID induction and RFID identification technology that allows cargo to be recognized automatically and checked by induction between tags and terminal readers. This application saves handling time in performing the inspection and receiving procedures of the cargo, and also reduces the time required. The use of RFID does not require a long time, the use of RFID can also reduce the risk of mistakes made by the operator in the process of transfer of cargo receipt

\section{Reference}

Hsu, C. I., Shih, H. H., \& Wang, W. C. (2009). Applying RFID to reduce delay in import cargo customs clearance process. Computers and Industrial Engineering, 57(2), 506-519. https://doi.org/10.1016/j.cie.2008.02.003

Kania, D. D. (n.d.). Analisis Faktor Budaya Keselamatan dan Kesehatan Kerja ( K3 ) Pada Penanganan Kargo Di Bandara Soekarno Hatta International Airport, 3(1), 1-13.

Kelemahan, F., Resky, M., \& Simarmata, J. (n.d.). FUNGSI dan KELEMAHAN UNIT OPERASI PELAYANAN DI BANDARA, 1-8. 
Ricardianto, R. P., \& Syaputra, H. (n.d.). PENINGKATAN EFEKTIVITAS PENANGANAN KARGO IMPOR UDARA, 9-24.

Sari, L. M. (2015). PENGIRIMAN PRODUK ARNOTTS KE ALFAMART AREA JABODETABEK DAN BANTEN PT INTAN UTAMA LOGISTIK TAHUN 2015, (3), 11-20.

Umagapi, B. W., Manajemen, S. T., Trisakti, T., Amonalisa, S., Manajemen, S. T., Trisakti, T., ... Trisakti, T. (2016). Bongkar Muat General Cargo the Documents Service Quality and the Speed, 3(3), 379-386. 